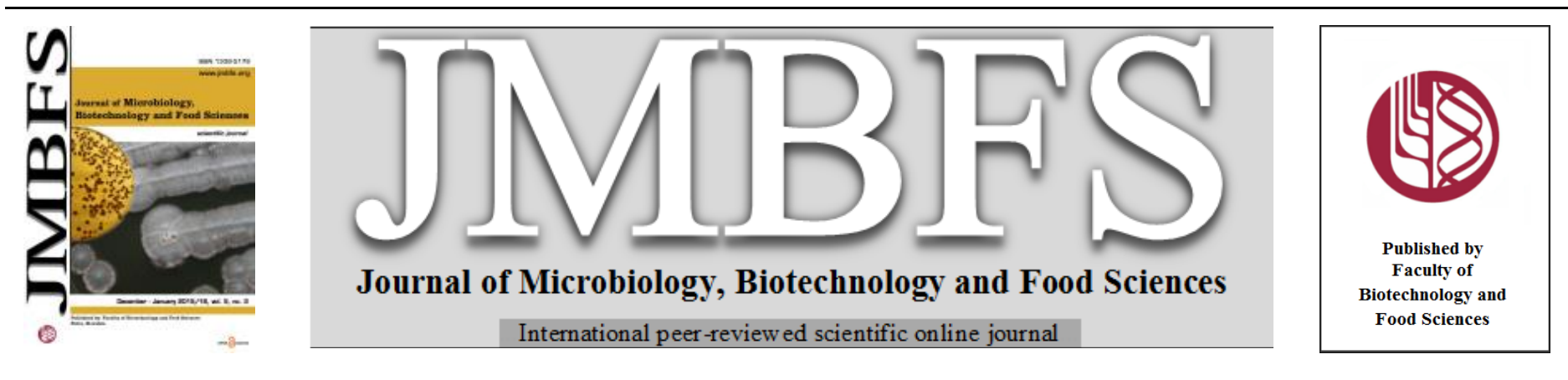

\title{
THE IMPACT OF PROBIOTIC BACTERIUM Lactobacillus acidophilus IN GROWTH AND SURVIVAL OF THE JUVENILE FRESH WATER RIVER PRAWN (Macrobrachium rosenbergii) INFECTED WITH PATHOGENIC Vibrio SPp.
}

\author{
Salahuddin Khan $*^{1}$ and Salma Mahmud ${ }^{2}$ \\ Address(es): Mr. Salahuddin Khan, \\ ${ }^{1}$ University of Chittagong, Faculty of Biological Science, Department of Microbiology, Hathazari, Postal Code 4331, Chittagong, Phone: $+880-31-721309$ \\ ${ }^{2}$ Chittagong Govt. College, Faculty of Science, Department of Zoology, College Road, Chawkbazar, Postal code 4203, Chittagong
}

*Corresponding author: salahuddin1187@gmail.com

doi: $10.15414 / j m b f s .2015 / 6.5 .3 .225-229$

\section{ARTICLE INFO}

Received 21. 4. 2015

Revised 3. 9. 2015

Accepted 9. 9. 2015

Published 1. 12. 2015

Regular article

open $\partial_{\text {ACCESS }}$

\begin{abstract}
The present study was performed to investigate the aptitude of Lactobacillus acidophilus 04 isolated from home made curd as a probiotic in treating the vibriosis of freshwater river prawn (Macrobrachium rosenbergii). Both in vivo and in vitro analyses were performed to test their efficacy. The antagonistic effect of cell free extract obtained from L. acidophilus 04 biomass was tested against three pathogenic Vibrio spp. namely Vibrio harveyi, V. vulnificus and $V$. anguillarum using disk diffusion method. The result showed inhibitory effects of cell-free extract on all three Vibrio spp. A feeding experiment was conducted for a period of 30 days by incorporating $L$. acidophilus in shrimp feed in three experimental $(\mathrm{T} 1, \mathrm{~T} 2, \mathrm{~T} 3)$ and one control groups. The result showed an increased gain in size and weight in experimental groups treated with L. acidophilus 04 compared to control group without any L. acidophilus 04 addition. The treatment groups were further challenged in vivo by inoculating shrimps with $10^{4}-10^{6}$ cells of pathogenic Vibrio harveyi, $V$. vulnificus and $V$. anguillarum. The histopatholgical and microbiological analysis revealed significant variation $(\mathrm{P}<0.05)$ in morbidity and mortality rates between the three treatment (T1, T2, T3) and one control (C) groups. The result of the study indicates an obvious improvement in growth and survival rate of juvenile freshwater prawns injected with pathogenic Vibrio spp. upon feeding with L. acidophilus supplement.
\end{abstract}

Keywords: Probiotic, Lactobacillus acidophilus, Macrobrachium rosenbergii, Vibriosis, Survival rate

\section{INTRODUCTION}

It is estimated by UN FAO that almost half of the world's seafood demand will be met by aquaculture in the year 2020 as the population of wild fisheries are rapidly declining due to erratic gorging and exploitation of natural aquatic habitats (Moriarty, 1999). Aquaculture is considered as one of the fastest growing industry in the arena of food production. It may suffice to understand the magnitude of its expansion that it grew at an annual rate of $16.8 \%$ between 1984 and 1995 . However, outbreak of diseases beset the aquaculture industry resulting enormous losses. One estimate of World Bank reports that the global losses due to shrimp diseases are around $\$ 3$ billion (Vaseeharan and Ramasamy, 2002) Vibriosis is considered one of the major reasons for the global loss resulted from bacterial diseases. Vibrio spp, predominantly occur in various developmental stages of Penaeus mondon. Mortality rate resulting from vibriosis is almost around $100 \%$ (Sivakumar et al., 2012). The people related to aquaculture industry thus opted to antibiotics to save their investments. However, the emergence of antibiotic resistant bacterial species and detrimental effects of various antibiotic residues have surfaced as even a greater concern for the consumers' health. Probiotics have recently attracted more attention as an alternative to antibiotics in aquatic disease management (Ninawe and Selvin, 2009). The beneficial effects of some bacterial species are well documented in human, cattle and poultry. Several studies suggest that Bacillus spp, Lactobacillus spp, Vibrio alginolyticus, pseudomonads, algae have potentials to act as probionts to treat bacterial diseases of shrimps and fishes (Austin et al. 1992, 1995; Smith and Davey, 1993). Most studies conducted so far on probiotic treatment of shrimps involved mostly seawater penaeid shrimps. However, some recent studies suggest that freshwater river prawns (Macrobrachium rosenbergii) suffer almost the similar fate with $100 \%$ mortality rate within one-day post injection (Siripornadulsil et al., 2013). So the present study was designed to evaluate the efficacy of a probiotic bacterial strain Lactobacillus acidophilus 04 on survival and growth of freshwater river prawn $M$. rosenbergii. The study aimed to investigate the ability of L. acidophilus to thwart the growth of Vibrio spp.

MATERIAL AND METHODS

\section{Identification of Bacterial strains}

Virulent strains of Vibrio harveyi, V. vulnificus, V. anguillarum were obtained from Fish Inspection and Quality Control Laboratory, Department of Fisheries, Chittagong. The strains were obtained in freeze-dried condition. So these strains were subjected to sub-culturing and were confirmed through standard morphological and biochemical techniques. They were further stored at $4^{\circ} \mathrm{C}$ in TCBS Agar. The probiotic bacterium L. acidophilus 04 was obtained from home made curd dilution plating on de Man Rogosa and Sharpe (MRS) Media (Himedia, India). Molecular characterization of all these bacterial strains was performed using 16S rDNA (Holt, 1994).

\section{Antagonism assay}

The preliminary antagonistic assay was performed by disk agar diffusion method (Bauer, 1966). V. harveyi, V. vulnificus , V. anguillarum were pre-cultured in Luria Bertani (LB) Broth at $28^{\circ} \mathrm{C}$ for 2 days . The cell free extracts of these bacterial strains were obtained as described previously (Sivakumar et al., 2012). The Vibrio strains were sub-cultured on TSA containing $1.0 \% \mathrm{NaCl}$ for $12 \mathrm{~h}$ at $30^{\circ} \mathrm{C}$. The plates of Muller Hinton Agar (Himedia, India) were flooded with 100 $\mu \mathrm{l}$ of Vibrio spp. and were air dried. Sterile disks (Himedia, India) were soaked with $20 \mu$ of cell-free extracts of L. acidophilus 04 and were placed on the air dried MHA plates containing Vibrio spp. Controls were prepared using disks impregnated with MRS broth (pH 6.5) and neutralized MRS broth. Both control and test plates were in triplicate and were subjected to incubation at $30^{\circ} \mathrm{C}$ for $24 \mathrm{~h}$ period. Antagonistic activity was defined as clear inhibitory zones around the disks.

\section{Feed Preparation}

L. acidophilus 04 was incubated at $30^{\circ} \mathrm{C}$ in MRS broth with continuous shaking for an overnight period. The cells were subjected to harvesting upon incubation by centrifugation at $2000 \mathrm{x}$ g. The harvest was washed twice using Phosphate 
Buffer Solution ( $\mathrm{pH}$ 7.2) and was re-suspended in the same solution. The absorbance at $600 \mathrm{~nm}$ was adjusted to $0.25 \pm 0.05$ in order to standardize the number of bacteria. The number of bacteria was enumerated by plating in 10 -fold dilutions. The CFU ml ${ }^{-1}$ in standard plate counts were correlated with absorbance at $600 \mathrm{~nm}$. Commercially available shrimp feed was procured to use as basal die for the supplementation of $L$. acidophilus 04 (ACI Godrej Agrovet, Bangladaesh). The commercially obtained feed was added to each L. acidophilus 04 biomass (LAB) and mixed thoroughly over a vortex mixer. A 10-fold dilution of $\mathrm{LAB}$ mixed with feed was prepared and the number of bacteria per ml was estimated at regular intervals of $24 \mathrm{~h}$ by standard plate count method on MRS Agar. The enumeration of bacterial biomass was in suspension was also conducted by measuring the optical density at $600 \mathrm{~nm}$. The final concentration $L$ acidophilus was $10^{6}$ cells $\mathrm{g}^{-1}$. A control was also prepared that contained the feed only without any addition of bacterial biomass.

\section{Feeding experiments}

A total of 600 juveniles of $M$. rosenbergii averaging $0.85 \pm 0.1 \mathrm{~g}$ in weight and $7 \pm 1 \mathrm{~cm}$ in length were obtained from a commercial hatchery of Baly Group Cox's Bazaar. The juveniles were transported in oxygen bags were measured from the tip of the telson to the base of the eye orbit before acclimatization in an aquarium made of fiber glass with capacity of 500 liter for a week. The juvenile shrimps were then allocated into 12 indoor glass aquaria measuring 100x50x50 $\mathrm{cm}$ at a rate of 50 animals per aquarium to maintain three replicates of the three treatment and one control groups with continuous aeration at $28 \pm 2{ }^{\circ} \mathrm{C}$ prior to commencement of the experiment. They were maintained on a pelleted diet supplemented with $L$. acidophilus 04 biomass concentration of $10^{6} \mathrm{cfu} \mathrm{ml}^{-1}$ and $15 \%$ of body weight in two individual doses per day at 12 hours interval (Ajitha, 2003). The feeding experiment was conducted one month prior to challenging the test shrimps with pathogenic Vibrio app. Five shrimps from each of the treatment and control groups were randomly sampled every week to measure the size and weight and histopatholgical analysis was performed to check for the signs of morbidity.

Table 1 The Physicochemical Parameters of the Glass aquaria

\begin{tabular}{lc}
\hline Parameter & Condition \\
\hline Salinity & $31.5 \pm 2 \%$ \\
\hline Oxygen & $4.5 \pm 0.5 \mathrm{mg} / 1$ \\
\hline Temperature & $28 \pm 1^{\circ} \mathrm{C}$ \\
\hline $\mathrm{pH}$ & $7.8 \pm 0.5$ \\
\hline
\end{tabular}

\section{In vivo Challenging with pathogenic Vibrio spp.}

After one month of regular feeding with L. acidophilus probionts, 20 shrimps from each of the treatment groups were injected with $10^{4}-10^{6}$ cells of $V$. harveyi, $V$. vulnificus and $V$. anguillarum, respectively. They were maintained segregated for next two weeks of post-infection in same conditions and were fed every second day and was observed for signs of morbidity and vibriosis. Ten shrimps surviving from each treatment and control groups were sampled and were microbiologically and histopathologically tested every week of post-infection period (Bell and Lightner, 1988). The feeding and observation for morbidity continued in the second week. The remaining inoculated shrimps were sacrificed and were subjected to microbiological and histopathological analysis. The uninoculated shrimps were also subjected to microbiological and histopathological analysis. Total viable count, total L. acidophilus and tota Vibrio from the gastro intestinal (GI) tract and tank water were counted before and after the vibrio challenging study by growth on marine agar, MRS agar and TCBS agar (Himedia, India), respectively.

\section{Detection of Lactic acid production}

Lactobacillus acidophilus 04 strain was inoculated into $10 \mathrm{ml}$ of MRS broth at an O.D. 600 of 0.05 and incubated statically at $37^{\circ} \mathrm{C}$ in a microaerobic incubator for $48 \mathrm{~h}$. Supernatants were collected from one $\mathrm{ml}$ of culture by centrifugation followed by passage through a $0.22 \mu \mathrm{m}$ filter to remove bacteria. The concentrations of D- and L-lactate in the cell-free supernatants were measured using stereo-specific D- and L-lactate assay kits (Eton Bioscience, San Diego, CA, USA). The measurements were performed in triplicate for reproducibility.
Assays were performed with pure solutions of D- and L-lactate to ensure that the kits were stereo-specific. (Neal-McKinney et al., 2012)

\section{Statistical analysis}

The results were analyzed by the Student's t-test to determine differences ( $\mathrm{P}<$ 0.05 ) between tested groups. All statistics were performed with SPSS for Windows, version 11.5 (SPSS Inc, Chicago, IL, USA).

\section{RESULTS}

\section{Antagonism Assay}

The cell-free extracts of the L. acidophilus showed inhibitory activity against all three Vibrio spp. The inhibitory effect was highest against $V$. harveyi followed by $V$. anguillarum and $V$. vulnificus respectively. The inhibitory effect was measured by the diameter of the clear inhibitory zones around the impregnated disks soaked with $L$. acidophilus extracts. The largest diameter of clear zone obtained was $21 \mathrm{~mm}$ against $V$. harveyi. The smallest diameter obtained was 13 $\mathrm{mm}$ for $V$. vulnificus. The control plates on the other hand formed no clear zone.

\section{Feeding experiment}

No morbidity was observed during the period of probiotic treatment of the shrimps. The juveniles that were procured were in sound health prior to acclimatization. All of the shrimps in the feeding experiment gained in size and weight during the trial of probiotic treatment. The mean final weight of the treatment groups were $1.52 \mathrm{~g}$ and that of the control group was $1.44 \mathrm{~g}$. The average gain in size of the treatment groups was $5.43 \mathrm{~cm}$. The same for the control group was $4.88 \mathrm{~cm}$. The histopathological analysis revealed no sign of bacterial diseases.

\section{In vivo challenging}

All three groups started to show the signs of morbidity due to vibriosis in the first week of in vivo challenging with Vibrio spp. However, the highest rate of morbidity was observed in the control group that received no probiotic treatment All of the three test groups showed reduced mortality. The mortality rate was also highest in the control group. The histopathological analysis of the first week revealed both localized and systemic lesions in the form of hemocytic nodules in gills, hemocel spaces and loose connective tissues. Histological analysis of hepatopancreas revealed no visible anomaly in the first week of infection. The morbidity and mortality rates increased in the final week of infection. The rate of mortality and morbidity was still highest in the control group. The uninoculated shrimps also developed the signs of morbidity in the final week. The histopathological analysis revealed multifocal lesions throughout the shells of the infected shrimps. Multifocal menalized hemocytic nodules were most common in the heart, lymphoid organ and gills. Table 2 describes the developing morbidity and mortality rates in the post infection period in all of the treatment and control groups.

Table 2 Morbidity and Mortality rates in treatment and control groups during in vivo challenging

\begin{tabular}{lcccc}
\hline Group & \multicolumn{2}{c}{ Morbidity rate (\%) } & \multicolumn{2}{c}{ Mortality rate (\%) } \\
\cline { 2 - 5 } & $\begin{array}{c}\text { First week } \\
\text { post } \\
\text { infection }\end{array}$ & $\begin{array}{c}\text { Second } \\
\text { week post } \\
\text { infection }\end{array}$ & $\begin{array}{c}\text { First week } \\
\text { post } \\
\text { infection }\end{array}$ & $\begin{array}{c}\text { Second week } \\
\text { post infection }\end{array}$ \\
\hline T1 & 41.50 & 56.54 & 7.50 & 14.20 \\
\hline T2 & 36.90 & 48.30 & 6.20 & 11.30 \\
\hline T3 & 43.00 & 57.25 & 7.80 & 15.30 \\
\hline C & 79.50 & 98.60 & 57.00 & 86.90 \\
\hline
\end{tabular}

Legends: $\mathrm{T} 1=$ Treatment group $1, \mathrm{~T} 2=$ Treatment group 2, T3 $=$ Treatment group $3, \mathrm{C}=$ Control group

The histopathological findings of the all four groups are also summarized in Table 3. The total viable count of the tail and hepato pancreas showed an increase in the bacterial population in the first week of post infection period. The $\mathrm{OD}_{600}$ analysis of the bacterial suspension grown in Nutrient Broth upon growing on agar media revealed the exponential growth of bacterial population during the first week. The following week showed a decline in the total plate count. Figure 1 shows the total bacterial growth at different stages. 
Table 3 Histopathology of the treatment and control groups upon inoculation of pathogenic Vibrio spp.

Number of developing pathological cases in each treatment and control group upon inoculation with pathogenic Vibrio spp.

Histopathological findings

\begin{tabular}{|c|c|c|c|c|c|c|c|c|}
\hline & \multicolumn{2}{|c|}{ (T1) } & \multicolumn{2}{|c|}{ (T2) } & \multicolumn{2}{|c|}{ (T3) } & \multicolumn{2}{|c|}{. } \\
\hline & Week 1 & Week 2 & Week 1 & Week 2 & Week 1 & Week 2 & Week 1 & Week 2 \\
\hline Melanized hemocytes forming capsules & 13 & 28 & 16 & 34 & 10 & 26 & 24 & 46 \\
\hline $\begin{array}{l}\text { Multifocal melanized hemocytic } \\
\text { nodules }\end{array}$ & 6 & 14 & 8 & 17 & 6 & 16 & 21 & 43 \\
\hline $\begin{array}{l}\text { Multifocal non-melanized hemocytic } \\
\text { nodules }\end{array}$ & 9 & 19 & 11 & 28 & 11 & 30 & 23 & 44 \\
\hline $\begin{array}{l}\text { Multifocal necrosis and hemocytic } \\
\text { inflammation of Hepatopancreatic } \\
\text { tubules }\end{array}$ & Nil & Nil & Nil & Nil & Nil & 1 & 7 & 15 \\
\hline
\end{tabular}

Table 4 Total L. acidophilus count in GI tracts of shrimps

\begin{tabular}{lcccc}
\hline Groups & \multicolumn{4}{c}{ Total L. acidophilus count $(\mathbf{c f u} / \mathbf{m l})$} \\
\cline { 2 - 5 } & $\begin{array}{c}\text { Before } \\
\text { feeding }\end{array}$ & $\begin{array}{c}\text { After } \\
\text { feeding for } \\
\text { 30 days }\end{array}$ & $\begin{array}{c}\text { First week } \\
\text { after } \\
\text { inoculation }\end{array}$ & $\begin{array}{c}\mathbf{2}^{\text {nd }} \text { week } \\
\text { after } \\
\text { inoculation }\end{array}$ \\
\hline T1 & Nil & $9.6 \times 10^{6}$ & $11.4 \times 10^{6}$ & $10.7 \times 10^{6}$ \\
\hline T2 & Nil & $7.8 \times 10^{6}$ & $9.4 \times 10^{6}$ & $8.8 \times 10^{6}$ \\
\hline T3 & Nil & $9.2 \times 10^{6}$ & $10.5 \times 10^{6}$ & $9.4 \times 10^{6}$ \\
\hline C & Nil & Nil & Nil & Nil \\
\hline
\end{tabular}

Legends: $\mathrm{T} 1=$ Treatment group $1, \mathrm{~T} 2=$ Treatment group 2, T3= Treatment group 3, $\mathrm{C}=$ Control group

All of the Vibrio spp and L. acidophilus 04 were identified in the juveniles tested at the end of final week of post-infection. The comparison of uninoculated shrimps tested both microbiologically and histopathologically of the treatment groups with that of uninoculated control group showed a massive difference. The rate of morbidity and mortality of the uninoculated treatment groups were very low $(23 \%)$ while the same was almost $96 \%$ for control group. Despite developing morbidity, the shrimps of the treatment groups gained in both size and weight The mean of the weight gained by the animals of the treatment groups was $2.69 \mathrm{~g}$ and the mean of the size gained by the treatment groups was $2.14 \mathrm{~cm}$. At the beginning, there was no observable L. acidophilus in the GI tract of the shrimps, however, the count increased significantly in the probiotic treatment groups. There was a slight decline in the L. acidophilus count at the final week of infection with Vibrio spp. The count for L. acidophilus in the water of the treatment group increased with the weeks of feeding. After challenging with Vibrio spp., the highest count of Vibrio was observed in the control groups. All three different Vibrio spp, were identified ( $V$. harveyi, $V$. vulnificus and $V$. anguillarum). The treatment groups, however, had a subtle increase in the count for vibrios. The count for Vibrio spp. reached its peak at the end of final week after challenging. Figure 2 depicts the growth of pathogenic Vibrio spp. at different stages ranging from the very beginning of the in vivo challenging experiment till the end of the experiment.

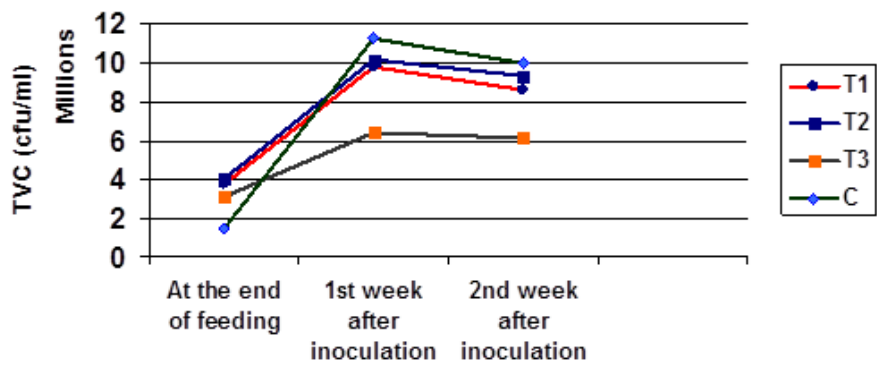

Figure 1 Total bacterial growth before and after inoculation of shrimps with pathogenic Vibrio spp.

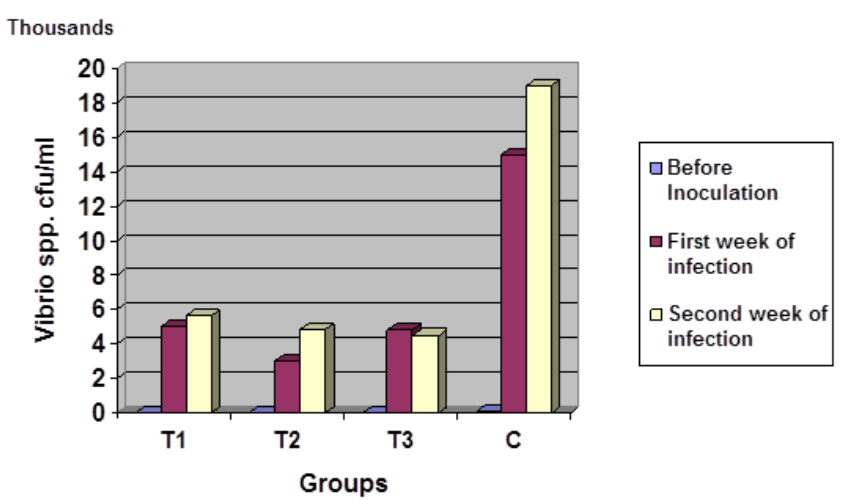

Figure 2 Growth of pathogenic Vibrio spp. after in vivo challenging

Lactic acid produced by L. acidophilus inhibits Vibrio spp.

To determine latic acid production, the amount of D- and L-lactic acid produced by $L$. acidophilus was measured using colorimetric enzymatic assay. The amount of lactic acid produced by $L$. acidophilus was $128 \pm 3.4 \mathrm{mM}$ D-lactate and $143 \pm 2.1 \mathrm{mM}$ L-lactate, respectively. The inhibition Vibrio spp. by lactic acid was determined by performing a survival experiment. Vibrio spp. were grown in LB broth supplemented with $\mathrm{NaCl}$. LB broth was treated with lactic acid and $\mathrm{HCl}$ to reach $\mathrm{pH}$ level $5.12,4.32$, and 3.46 , respectively. Control ledia were also maintained that were not treated. Five $\mathrm{ml}$ of each broth were inoculated with Vibrio spp. in triplicate, and samples were taken at $1,2,4$, and $8 \mathrm{~h}$ for bacterial enumeration. There was a complete inhibition of Vibrio growth in media containing $100 \mathrm{mM}$ lactic acid in $1 \mathrm{~h}$. Media containing $25 \mathrm{mM}$ lactic acid resulted in the death of all Vibrio spp. by $2 \mathrm{~h}$, while treatment media at $\mathrm{pH} 4.32$ $(\mathrm{HCl})$ did not kill all Vibrio until $8 \mathrm{~h}$. Media containing $10 \mathrm{mM}$ lactic acid or $\mathrm{pH}$ $5.12(\mathrm{HCl})$ inhibited Vibrio spp. growth slightly compared to the untreated medium.

\section{DISCUSSION}

Vibriosis has been recognized as one of the major causes responsible for mortality of cultured shrimp world wide. The potential negative consequences and reduced efficacy of antimicrobial agents necessitated the search for an alternative (Farzanfar, 2006). The use of probiotics has increasingly being recognized as a safer and more effective method of controlling diseases. Lactobacillus spp. has always been at the center of interest due to its beneficial features on animal and human (Verschuere et $\boldsymbol{a l . , 2 0 0 0 ) . ~ S e v e r a l ~ s t u d i e s ~}$ suggest that probiotic bacteria are capable of exerting antagonistic effect against pathogenic vibrios in penaeid shrimps (Vaseeharan and Ramasamy 2003, Rengipat 2000, Sivakumar et al., 2013). The present study showed similar inhibitory action as the cell-free extract obtained from L. acidophilus 04 formed clear zones around the disks applied on the surface flooded with pathogenic Vibrio spp. There are reports suggesting the ability of Lactobacillus to alter the $\mathrm{pH}$ and production peptide antibiotic, bacteriocins capable of inhibiting the growth of both gram-positive and gram negative bacteria (Chaurasia et al. 2005; Yilmaz et al., 2006; Enserink, 1999; Zhou et al., 2005). The bacteriocin producing strain L. acidophilus was isolated from the gut of Penaeus monodon (Karthikeyan and Santhosh, 2009).

The supplementation of feed with probiotic bacteria might positively influence the growth and survival of freshwater prawns. The treatment groups in the present study gained size and weight significantly during the period of 30 days of feeding experiment. The retarded growth of the juvenile freshwater prawns of the control group is a strong indication that the probiotic supplement had a positive impact on the growth and survival rate of the shrimps in test. The finding of Seenivasan et al. (2012) is in agreement with the result of the present study. 
They observed that the growth parameters such as survival, weight gain, geed conversion efficiency and protein efficiency rate of $M$. rosenbergii were significantly higher $(\mathrm{p}<0.05)$ in $3 \%$ Lactobacillus sporogenes, Bacillus subtilis and Saccharomyces cerevisiae incorporated diet fed.

The in vivo challenging experiment showed significant reduction in morbidity and mortality rates in the groups fed with L. acidophilus 04 supplement. The morbidity and mortality rates were much higher in the control group. The mortality rate was 8-10 folds higher in all three treatment groups compared to untreated control groups. Sivakumar et al. (2012) reported six-fold higher survival rate in treatment groups of penaeid shrimps (Penaeus monodon) fed with probiotic bacterium L. acidophilus compared to untreated control groups upon exposure to pathogenic Vibrio spp. The increase in the Vibrio spp. and $L$ acidophilus count in the first week following the inoculation of shrimps with pathogenic bacteria suggests exponential growth phase. The slump of bacterial count at the end of experiment can be result of nutrition attrition (Llorens $\boldsymbol{e t}$ al., 2010)

Results of the histopathological examination revealed melanized hemocyte forming plugs in all groups at the first week of post-exposure period of the study. Such lesions are suggestive of localized vibriosis (Baticados et al., 1990) However, there were no multifocal melanized hemocytic nodules at the end of first week of infection in the treatment groups. The control groups did develop some multifocal melanized hemocytic nodules in the first week but it saw a massive upsurge in the second week of infection. All of the groups developed multifocal melanized hemocytic nodules and non- melanized hemocytic nodules at the end of second week upon inoculation with pathogenic Vibrio spp. These nodules are considered as principal diagnostic feature of systemic vibriosis (Lightner, 1996). The control groups developed such chronic inflammatory lesions 10-fold higher than in the treatment groups. There were no multifoca melanized hemocytic nodules in the hepato pancreas of the shrimps in the treatment groups even after exposure for two weeks. The control groups however, did develop such inflammatory lesions in the hepato pancreatic tubules suggesting septic hepatopancreatitis (Ambipillai, 2003). Pathogenic Vibrio spp. were isolated from the hepato pancreas of shrimps in control group. The Vibrio count of the treatment groups was low compared to that of control group, which could be the result of secretion of inhibitory peptides. Reports suggest that probiotic bacteria colonize the GI tract of the shrimp to prevent the adhesion of pathogenic bacteria (Gomez-Gill et al., 2000). Acids produced by the LAB can also be another factor that inhibits the growth of pathogenic Vibrio spp (Vinothkumar et al., 2011). Our present study indicates that lactic acid produced by $L$. acidophilus inhibits the growth of pathogenic Vibrio spp. through both $\mathrm{pH}$ dependent and $\mathrm{pH}$-independent mechanisms. Previous study also suggests that supplementation of Luria-Bertani broth containing $0.3 \%$ agar with norepinephrine and dopamine $(100 \mu \mathrm{M})$ significantly induced the motility of tested strains of Vibrio spp., which is in concurrence with our present investigation (Suong, 2013). The impact of Lactobacillus acidophilus to induce host response to the infection by pathogenic Vibrio spp. is yet to be revealed.

\section{CONCLUSION}

The study concluded that the bacterial biomass of L. acidophilus can be used as a dietary supplement of freshwater prawn $M$. rosenbergii to deter infection by pathogenic Vibrio spp. The influence of probiotics to induce host immune response could be a further course of study. The specific roles of antibacterial products produced by the $L$. acidophilus can also invite researchers to investigate deeper into the matter

\section{REFERENCES}

AJITHA, S., SRIDHAR, M., SRIDHAR, N., SINGH, I.S.B., VARGHESE, V. 2004. Probiotic effects of lactic acid bacteria against Vibrio alginolyticuys in Penaeus (Fenneropenaeus) indicus (H. Milne Edwards). Asian Fish Sci. 17, 7180.

AMBIPILLAI, L., SOBHANA, K.S., GEORGE, K.C. AND SANIL, N.K. 2003 Histopathological survey of cultured shrimps in Cochin, Kerala. J. mar. biol. Ass India, 45 (2), 178 - 185

AUSTIN, B., BAUDET, E. AND STOBIE, M. 1992. Inhibition of bacteria fish pathogens by Tetraselmis suecica. Journal of Fish Dieases. 15:53-61. http://dx.doi.org/10.1111/j.1365-2761.1992.tb00636.x

AUSTIN, B., STUCKEY, L. F., BERTSON, P. A. W., EFFENDI, I. AND GRIFFITH, D. R. W. 1995. A probiotic strain of Vibrio alginoyticus effective in reducing diseases caused y Aeromonas salmoniioda. Vibrio anguillarum and Vibrio ordalii. Journal of Fish Diseases 18:93-96. http://dx.doi.org/10.1111/j.1365-2761.1995.tb01271.x

BATICADOS, M.C.L., CRUZ-LACIERDA, E.R., DE LA CRUZ, M.C., DUREMDEZ-FERNANDEZ, R.C., GACUTAN, R.Q., LAVILLAPITOGO, C.R. AND LIO-PO, G.D. 1990b. Diseases of Penaeid Shrimps in the Philippines. Aquaculture Extension Manual No. 16. Aquaculture Department, Southeast Asian Fisheries Development Center (SEAFDEC), Tigbauan, Iloilo, Philippines. 46 p. ISBN 971-85 11-27-X
BAUER, A.W., KIRBY, W.M.M., SHERRIS, J.C. AND TURCK, M. 1966 Antibiotic susceptibility testing by a standard single disc method. American Journal of Clinical Pathology, 45, 493-496.

BELL, T. A. AND LIGHTNER, D. V.. 1988. A handbook of normal penaeid shrimp histology. The world Aquaculture Society, Baton Rouge, Lousiana, USA 114 pp. ISBN-13: 978-09-35 868-37-1 http://dx.doi.org/10.1016/0044 8486(89)90090-2

CHAURASIA, B., PANDEY, A., PALNI, L.M.S., TRIVEDI, P., KUMAR, B. COLVIN, N. 2005. Diffusible and volatile compounds produced by an antagonistic Bacillus subtilis strain cause structural deformations in pathogenic fungi in vitro. Microbiol. Res. 160, 75-81. http://dx.doi.org/10.1016/j.micres.2004.09.013

ENSERINK, M. 1999. Promising antibiotic candidate identified. Science 286, 2245-2247. http://dx.doi.org/10.1126/science.286.5448.2245

FARZANFAR, A. 2006. The use of probiotics in shrimp aquaculture. FEMS Immunol. Med. Microbiol. 48,149-158. http://dx.doi.org/10.1111/j.1574 695x.2006.00116.x

GOMEZ-GIL, B., ROQUE, A., TURNBULL, J.F. 2000. The use and selection of probiotic bacteria for use in the culture of larval aquatic organisms. Aquaculture 191, 259-270. http://dx.doi.org/10.1016/s0044-8486(00)00431-2

HOLT, J.G., KRIEG, N.R., SNEATH, P.H.A. AND STALEY, J.T. (ed.). 1994 Facultatively anaerobic Gram negative rods. In Bergey's Manual of Determinative Bacteriology, 9th edn. pp. 175-289. Baltimore, MD,USA Williams \& Wilkins. ISBN : 978-06-83 006-03-2 http://dx.doi.org/10.1002/jobm.3620251024

KARTHIKEYAN, V., SANTHOSH, S.W. 2009. Study of Bacteriocin as a Food Preservative and the L. acidophilus Strain as Probiotic. Pak. J. Nutr. 8, 335-340. http://dx.doi.org/10.3923/pjn.2009.335.340

LIGHTNER, D.V. 1996. A Handbook of Shrimp Pathology and Diagnostic Procedures for Diseases of Cultured Penaeid Shrimp. pp. 1-72. Baton Rouge LA, USA: World Aquaculture Society. ISBN-13: 978-0962452994

LLORENS, J.M.N., TORMO, A. AND MARTINEZ-GARCIA, E. 2010 Stationary phase in gram-negative bacteria. FEMS Microbiol Rev. 34, 476-495. http://dx.doi.org/10.1111/j.1574-6976.2010.00213.x

MORIARTY, D.J.W. 1999. Disease Control in Shrimp Aquaculture with Probiotic Bacteria. Microbial Interactions in Aquaculture. (Proceedings of the 8th International Symposium on Microbial Ecology). Atlantic Canada Society for Microbial Ecology, Halifax: Canada, 237-243.

NEAL-MCKINNEY, J.M, LU, X., DUONG, T., LARSON, C.L., CALL, D.R. SHAH, D.H., AND KONKEL, M.E. 2012. Production of Organic Acids by Probiotic Lactobacilli Can Be Used to Reduce Pathogen Load in Poultry. PLOS one http://dx.doi.org/10.1371/journal.pone.0043928

NINAWE, A.S. AND SELVIN, J. 2009. Probiotics in shrimp aquaculture: Avenues and challenges. Cric Reviews in Microbiology, 35(1), 43-66. http://dx.doi.org/10.1080/10408410802667202

RENGIPIPAT, S., RUKPRATANPORN, S., PIYATIRATITIVORAKUL, S AND MENASAVETA, P. 2000. Immunity enhancement in black tiger shrimp (Penaeus monodon) by a probiont bacterium (Bacillus S11). Aquaculture. 191, 271-288. http://dx.doi.org/10.1016/s0044-8486(00)00440-3

SEENIVASAN, C., BHAVAN, P.S., RADHAKRISHNAN, S. MURALISANKAR, T. 2012. Effects of Probiotics on Survival, Growth and Biochemical Constituents of Freshwater Prawn Macrobrachium rosenbergii Pos Larvae. Turkish Journal of Fisheries and Aquatic Sciences 12, 331-338. http://dx.doi.org/10.1016/j.jobaz.2013.12.002

SIRIPORNADULSIL, W., THONGSERM, M AND SIRIPORNADULSIL, S 2013. Pathogenicity of halophilic Vibrio harveyi in giant freshwater prawns (Macrobrachium rosenbergii De Man). Aquaculture Research. 45, 12, 1979 1988. http://dx.doi.org/10.1111/are.12144

SIVAKUMAR, N., SUNDARARAMAN, M., SELVAKUMAR, G. 2012 Probiotic effect of Lactobacillus acidophilus against vibriosis in juvenile shrimp (Penaeus monodon). African Journal of Biotechnology, 11(91), 15811-15818 http://dx.doi.org/10.5897/AJB12.1328

SMITH, D. AND DAVEY, S. 1993. Evidence for the competitive exclusion of Aeromonas Salmenicida from fish with stress-inducible furrnculosis by a fluorescent pseudomonad. Journal of fish disease. 16: 521-524. http://dx.doi.org/10.1111/j.1365-2761.1993.tb00888.x

SUONG, N.T. 2013. The impact of host stress hormones on vibriosis in the larvae of giant river prawn (Macrobrachium rosenbergii), University of Ghent VASEEHARAN, B. AND RAMASAMY, P. 2003. Control of pathogenic Vibrio spp. by Bacillus subtilis BT23, a possible probiotic treatment for black tiger shrimp Penaeus monodon. Lett Appl Microbiol , 36, 83-87. http://dx.doi.org/10.1046/j.1472-765x.2003.01255.x

VERSCHUERE, L., ROMBAUT, G., SORGELOOS, P., VERSTRAETE, W. 2000. Probiotic bacteria as biological control agents in aquaculture. Microbiol Mol. Biol. Rev. 64, 655-671. http://dx.doi.org/10.1128/mmbr.64.4.655-671.2000 VINOTHKUMAR, P., SHEIK, M.P., AYSHA, O.S., VALLI, S., NIRMALA, P., REENA, A., ELUMALAI, E.K. 2011. Microbial Product Act As a Probiotic against Human Intestinal Pathogens. Int. J. Pharmaceut. Biol. Arch. 2, 1172 1174 . 
YILMAZ, M., SORAN, H., BEYATLI,Y. 2006. Antimicrobial activities of some Bacillus spp. strains isolated from the soil. Microbiol. Res. 161, 127-131. http://dx.doi.org/10.1016/j.micres.2005.07.001

ZHOU, X.X., YAO, J.T., LI, W.F. 2005. Isolation and identification of Lactococcus lactis producing nisin. J. Zhejiang Univ. Agriculture \& Life Sciences. 31, 645-648 